Article

\title{
Characteristics of a Low-Sulfidation Epithermal Deposit in the River Reef Zone and the Watuputih Hill, the Poboya Gold Prospect, Central Sulawesi, Indonesia: Host Rocks and Hydrothermal Alteration
}

\author{
Syafrizal ${ }^{1}$, Tomy Alvin Rivai ${ }^{2}$, Kotaro Yonezu ${ }^{2}$, Damar Kusumanto ${ }^{3}$, Koichiro Watanabe ${ }^{2}$ and \\ Arie Naftali Hawu Hede ${ }^{1, *}$ \\ 1 Earth Resources Exploration Research Group, Faculty of Mining and Petroleum Engineering, Institut \\ Teknologi Bandung, Jl. Ganesha 10, Bandung 40132, Indonesia; syafrizal@mining.itb.ac.id \\ 2 Department of Earth Resources Engineering, Graduate School of Engineering, Kyushu University, \\ 744 Motooka, Nishiku, Fukuoka 819-0395, Japan; tomyalvinrivai@mine.kyushu-u.ac.jp (T.A.R.); \\ yone@mine.kyushu-u.ac.jp (K.Y.); wat@mine.kyushu-u.ac.jp (K.W.) \\ 3 PT Bumi Resources Minerals Tbk., Wisma Bakrie 2, Rasuna Said B-2, Jakarta 12920, Indonesia; \\ damar.kusumanto@brm.co.id \\ * Correspondence: naftali@mining.itb.ac.id; Tel.: +62-22-250-2239
}

Received: 28 May 2017; Accepted: 16 July 2017; Published: 19 July 2017

\begin{abstract}
Systematic exploration has delineated significant gold mineralization in the River Reef Zone and the presence of a siliceous body at Watuputih Hill, which is a Poboya gold prospect in Central Sulawesi, Indonesia. The mineralization is hosted within the Palu Metamorphic Complex. The host rocks consist of granite, biotite gneiss, and biotite schist, which is intercalated by feldspar porphyroblastic biotite schist and amphibolitic schist. The X-ray fluorescence (XRF) analysis of the granite and biotite gneiss suggests that the granitic rocks can be characterized as magnesian arc calc-alkaline rocks, with a weakly peraluminous composition. Alteration minerals were analyzed by a combination of petrographic and X-ray diffraction (XRD). In the River Reef Zone, the hydrothermal alteration zones can be sorted by their proximity to the primary fluid conduit and divided into inner, high-T, and low-T propylitic zones. In Watuputih Hill, the hydrothermal alteration can be divided into advanced argillic and argillic zones. The hydrothermal alteration assemblages indicated that the fluid was at a near-neutral $\mathrm{pH}$ in the River Reef Zone, whereas the fluid was acidic within Watuputih Hill. Because the hill is relatively distant from the River Reef Zone, the presence of these zones at Watuputih Hill may be indicative of another mineralization system beneath the hill.
\end{abstract}

Keywords: host rock; hydrothermal alteration; gold mineralization; the Poboya gold district

\section{Introduction}

The Poboya gold prospect is located approximately $12 \mathrm{~km}$ to the northeast of Palu City. Gold mineralization at this prospect is outlined by three vein zones, namely the River Reef Zone (RRZ), the Hill Reef 1 Zone (HRZ-1), and the Hill Reef 2 Zone (HRZ-2). An intensive drilling program conducted in the RRZ resulted in a delineated orebody that contains 18 million metric tons of ore at $3.4 \mathrm{~g} / \mathrm{t}$ $\mathrm{Au}$ [1]. A preliminary exploration performed to the southwest of the RRZ discovered the presence of a siliceous deposit known as Watuputih Hill (WPH).

Wajdi et al. [2] have documented that quartz-carbonate veins cutting through host rocks in RRZ exhibit several textures that are characteristic of low-sulfidation epithermal deposits. These textures include colloform-crustiform banding, bladed calcite, massive chalcedony, and comb banded quartz. The occurrence of brecciation suggests multi-episode hydrothermal fluid injections. 
High-grade mineralization was detected concurrently with the presence of grey sulfide lines in quartz-carbonate veins.

Gold-bearing arcs in Sulawesi Island can be divided into the North Sulawesi and the West Sulawesi Arcs [3,4]. The North Sulawesi Arc hosts a considerable number of gold mineralization [5-8]. Its island arc tectonic setting and the widely distributed volcanic rocks throughout the arc make the North Sulawesi Arc attractive for gold exploration [9,10]. Conversely, the West Sulawesi Arc appeared to be less favorable for gold mineralization because of its collisional tectonic setting and metamorphic rock-dominated terrane [11]. However, as depicted in Figure 1a, several occurrences of gold placer deposits along the Palu-Koro Fault Zone (PKFZ) may shift the previous perspective regarding the unattractiveness of the West Sulawesi Arc for gold exploration.
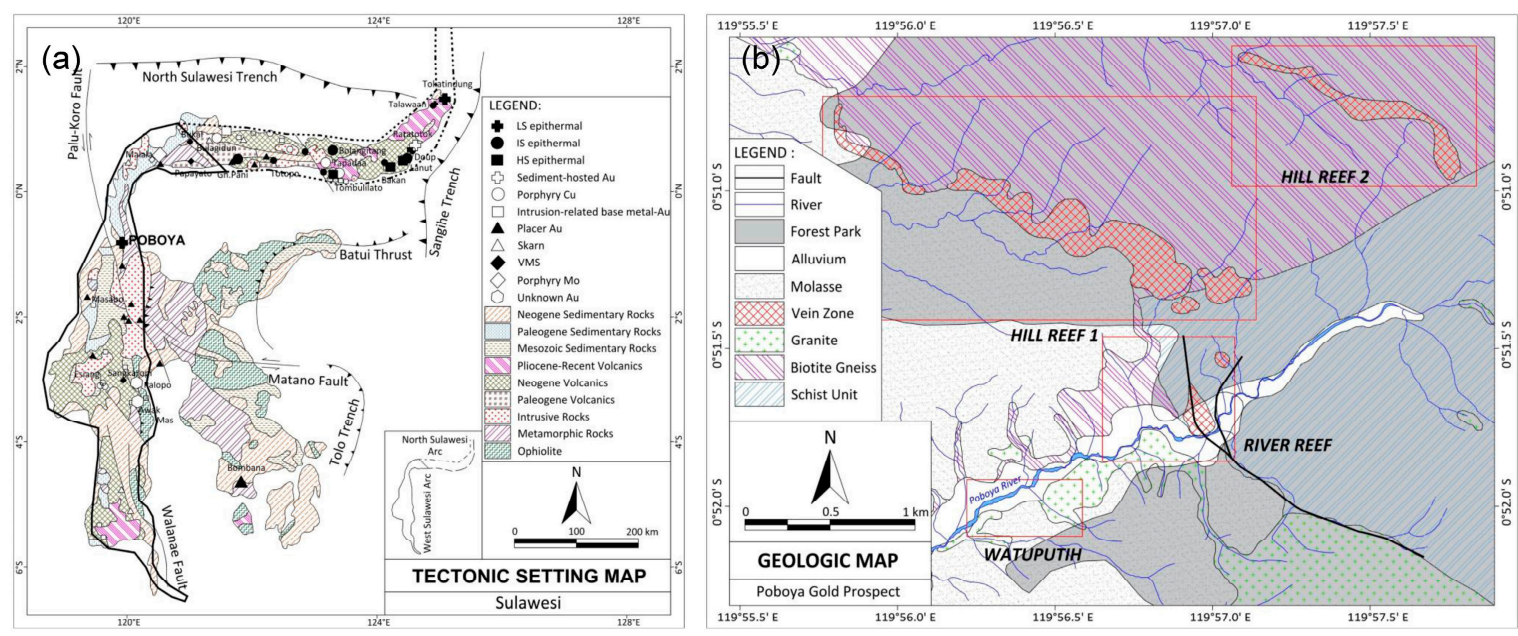

Figure 1. (a) Map of mineralized arc modified after Garwin et al. [4]: tectonic setting and gold deposit occurrences in Sulawesi (modified after [1]). In contrast to the predominantly volcanic North Sulawesi Arc, the West Sulawesi Arc hosts less gold mineralization; (b) Geologic map of the Poboya gold prospect. While metamorphic rocks intruded by granite outcrop in the northeastern part of the prospect, the southwestern part of the prospect is covered by molasse deposit.

The discovery of primary gold mineralization in Poboya is a significant milestone for gold exploration in the West Sulawesi Arc, especially along the PKFZ. Because exploration data in RRZ and WPH are available and a detailed study has not been performed, an investigation of this zone is essential. Moreover, the Poboya gold district is expected to be developed soon under the concession of Perseroan Terbatas (PT; a limited liability company in Indonesia) Citra Palu Minerals (a subsidiary of PT Bumi Resources Minerals, Tbk.), a gold mining company in Indonesia. In this paper, we present our work related to the host rocks and hydrothermal alteration occurring in the RRZ and WPH. The host rock study emphasizes their microscopic and geochemical characteristics. The results of this study provide insights into the origin of the rocks, the corresponding tectonic setting, and the differences among the rocks encountered in this zone. The hydrothermal alteration study is used to characterize alteration mineral assemblages occurring in the rocks. The assemblages and their original rock-forming minerals provide information regarding the hydrothermal fluid characteristics and their interactions with wall rocks. Because the alteration mineral assemblages extend beyond the orebody, such studies are important for gold exploration [12] and provide a better understanding of the gold mineralization at this prospect.

\section{Geologic Background}

The Poboya gold prospect lies on the central portion of Western Sulawesi Province, which is a part of the Sundaland continental margin [13] (see Figure 1a). The area from Palu to the neck of Sulawesi is 
built on the Palu Metamorphic Complex (PMC) basement rocks. The PMC consists of biotite gneiss, biotite schist, amphibole, and amphibolitic schists. Several higher-grade metamorphic rocks also occur in this complex, such as granulite, eclogite, and garnet peridotite [14]. This metamorphic complex is derived from Permo-Triassic metagranitoids and metasediments of Australia-New Guinea, metabasites of mid-ocean ridge basalts affinity, and Sundaland-origin rocks [15].

The PMC is subsequently overlain by Tertiary volcano-sedimentary strata known as the Tinombo Formation. Late Cenozoic granitic rocks intrude the basement and the volcano-sedimentary formation throughout the area. A rapid exhumation event occurred in the area and led to extensive weathering, which resulted in Quaternary Celebes Molasse sediments. The sediments flank the uplifted metamorphic core complex along the neck of Sulawesi [13].

Katili [16] mentioned that the geological structures in the neck of Sulawesi are prominently controlled by the PKFZ extending in the NNW-SSE direction. The PKFZ starts from the tip of the Matano Fault in the south and ends at the western-most side of the North Sulawesi Trench. Other lineaments are subparallel to the PKFZ [17]. In the Palu area, the PKFZ is a pull-apart basin hosting the Poboya gold prospect located in the eastern margin of the basin [2].

In the Poboya gold prospect, a detailed geological map indicates the presence of biotite gneiss and schist as the predominant rocks at the southwestern portion of the prospect. These rocks are further intruded by small distributed granite. As an erosion product of these rock units, molasse sediments widely cover this area. Conversely, because of the restriction on entering the Poboya Forest Park, rocks at the northeastern portion of the prospect are generalized to be composed of biotite gneiss and schist as suggested by a preliminary geological map of this area (Figure 1b).

\section{Materials and Methods}

This study employed four methods: macroscopic observation, petrography, X-ray diffraction (XRD), and X-ray fluorescence (XRF). Host rocks were described both macroscopically and microscopically. Microscopic observations were conducted through thin sections with a thickness of approximately $0.03 \mathrm{~mm}$. The geochemistry of the host rocks was analyzed using XRF. In this study, we used a polarizing microscope called Nikon ECLIPSE E600POL (Nikon Corporation, Tokyo, Japan) and a Rigaku RIX3100 (Rigaku Corporation, Tokyo, Japan) to conduct petrographic and XRF analyses, respectively.

To investigate the hydrothermal alteration, thin sections were prepared using the same procedure described for the host rocks. For several samples, the bulk composition was verified using an XRD machine, the RIGAKU Ultima IV X-ray Diffractometer (Rigaku Corporation, Tokyo, Japan). The double incident angle $(2 \theta)$ used in this investigation ranged from $0^{\circ}-65^{\circ}$, with a scanning interval of $0.02^{\circ}$.

The clay fraction was also analyzed using the same machine and a $2 \theta$ range from $0^{\circ}$ to $40^{\circ}$. This fraction was separated by a series of elutriation sequences. The separated fraction was then mounted and air dried on a glass slide. Supplementary treatments using ethylene glycol and hydrochloric acid were applied to verify the presence or absence of clay minerals, which possess nearly overlapping diffraction patterns. All analyses were performed at the Laboratory of Economic Geology at Kyushu University.

In the RRZ, samples were collected from boreholes POBO0036, POBO0040, and POBO0044 as well as from outcrops. In total, 18 core and 5 outcrop samples were analyzed to characterize the host rocks. Nearly 40 core and 13 outcrop samples were examined to delineate the hydrothermal alteration. Conversely, 8 outcrop samples were collected from the peak and the hillside of WPH to analyze both the host rocks and the hydrothermal alteration. The sample localities are depicted in Figure 2. 


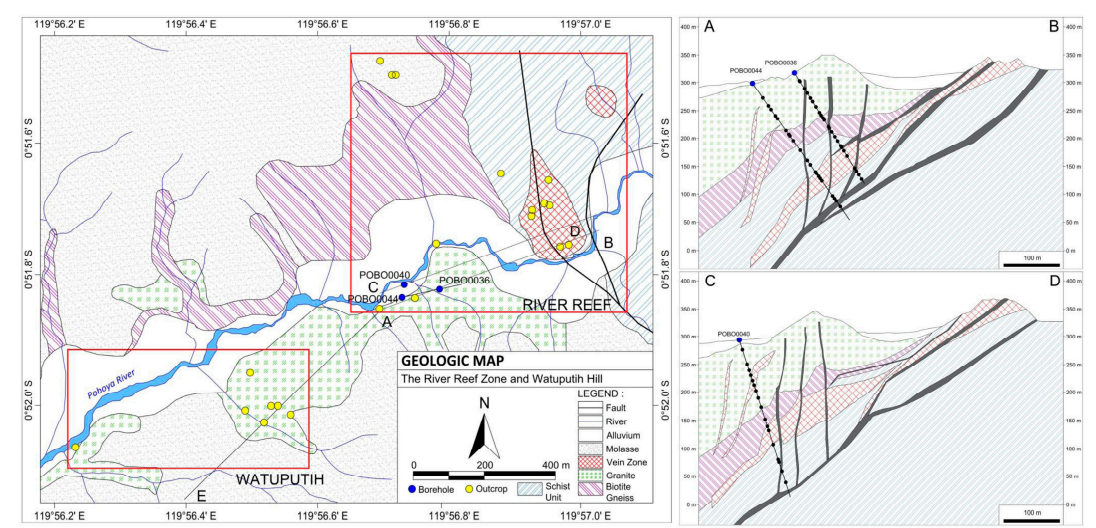

Figure 2. Sample localities in River Reef Zone (RRZ) and Watuputih Hill (WPH). Outcrop samples were collected from 14 and 7 points in RRZ and WPH, respectively. Core samples were collected from boreholes POBO0036, $\mathrm{POBO} 0044$, and POBO0040, representing two completed drilling sections in the RRZ (sections $A B$ and $C D$ ).

\section{Results}

\subsection{Host Rock Descriptions and Geochemistry Results}

Sorted from the uppermost portion of the RRZ, three primary rock units can be identified: granite, biotite gneiss, and schist. The schist unit is dominated by biotite schist, which is intercalated by feldspar porphyroblastic biotite schist and amphibolitic schist. Granite, biotite gneiss, biotite schist, and amphibolitic schist crop out in the RRZ, whereas feldspar porphyroblastic biotite schist can be found only in borehole samples. In WPH, the host rock is composed of only granite.

Granite is composed essentially of quartz, orthoclase, and plagioclase. Quartz and orthoclase are more predominant than plagioclase. Biotite, allanite, zircon, sphene, and apatite occur as accessory minerals. Myrmekitic intergrowths, hollocrystallinity, interlocking, and phaneritic textures are observed in this rock (Figure 3a).

The biotite gneiss composition resembles that of granite with the addition of biotite and hornblende as essential and accessory minerals, respectively. The plagioclase content within this rock is more abundant than that in the granite. Similar to the granite, this rock also has a myrmekitic texture. Segregated bands of light and dark minerals can be easily observed at the hand-specimen scale. The poor alternation of these bands shows a gneissose structure that defines a poorly developed schistosity (Figure 3b).

The biotite schist is primarily composed of quartz, orthoclase, plagioclase, and biotite. Sphene occurs as an accessory mineral in this rock. The rock foliation can be observed under a microscope. The schistosity of this rock is much stronger than that of the biotite gneiss. Asymmetrical crenulations and flattened quartz are also observed (Figure 3c).

The feldspar porphyroblastic biotite schist is composed principally of orthoclase, plagioclase, and biotite. Quartz, hornblende, sphene, and apatite are identified as accessory minerals. The foliation of this rock is deflected by the growth of feldspar porphyroblasts. In addition to occurring within the foliation, sphene, zircon, biotite, and apatite occur as inclusions within the feldspar porphyroblasts as well (Figure 3d).

The amphibolitic schist has a similar macroscopic appearance to the biotite schist. This rock is composed primarily of quartz, plagioclase, and hornblende. Plagioclase is much more abundant in the amphibolitic schist than in the previously described rocks. The accessory minerals of this rock consist of orthoclase and sphene. The schistosity is similar to that of the biotite schist. Flattened plagioclase and quartz as well as lineated hornblende are the prominent characteristics of this rock (Figure 3e). 
(a)
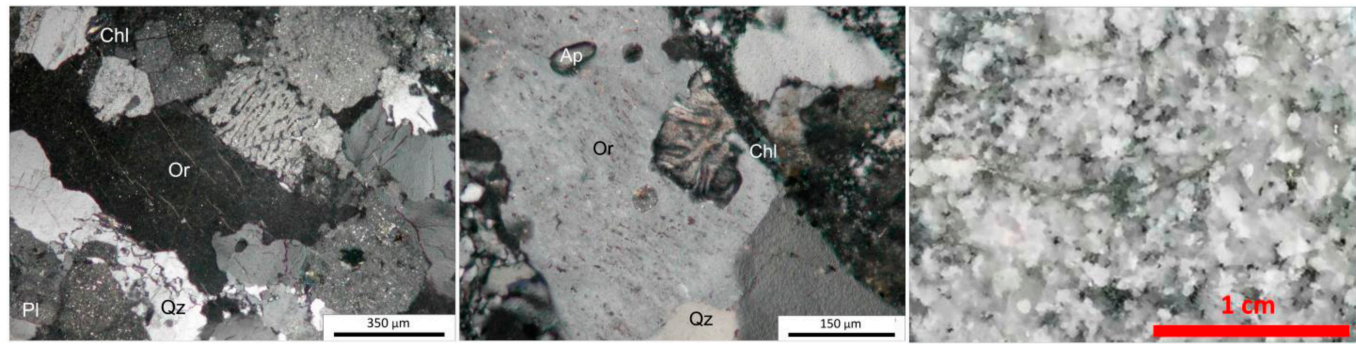

(b)
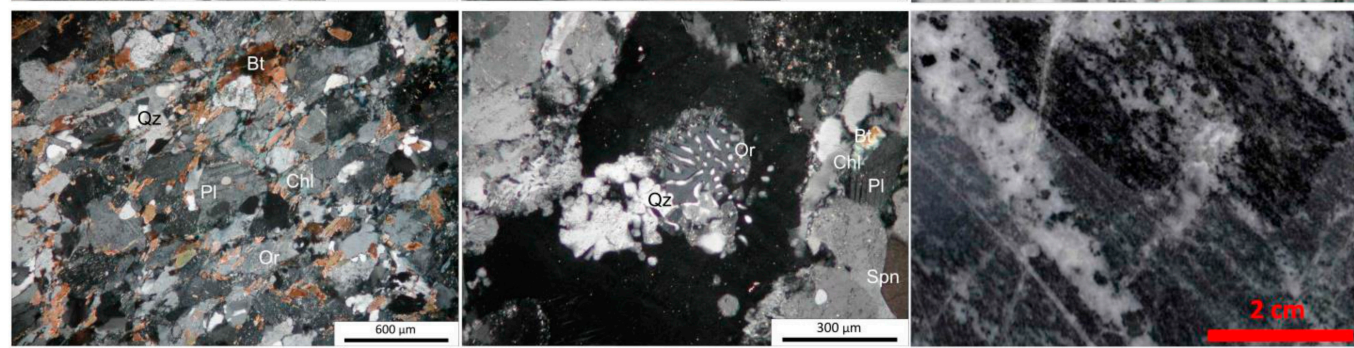

(c)
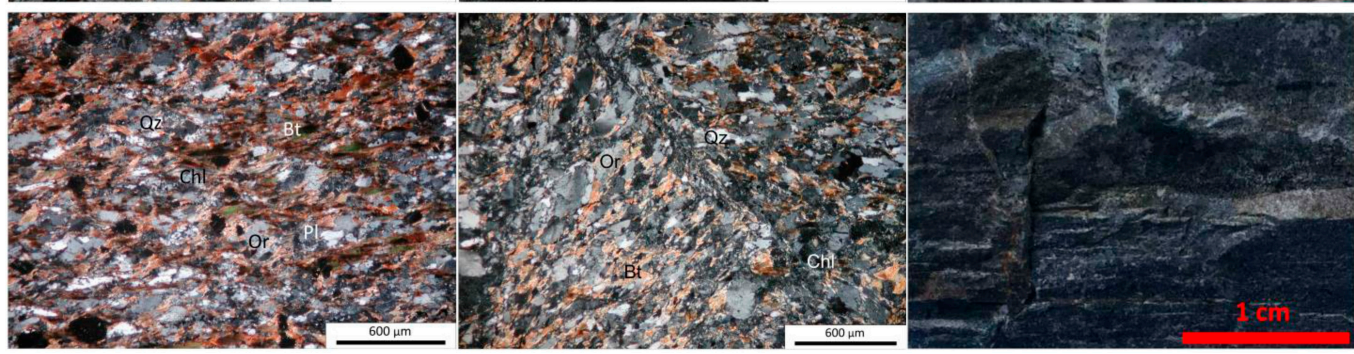

(d)
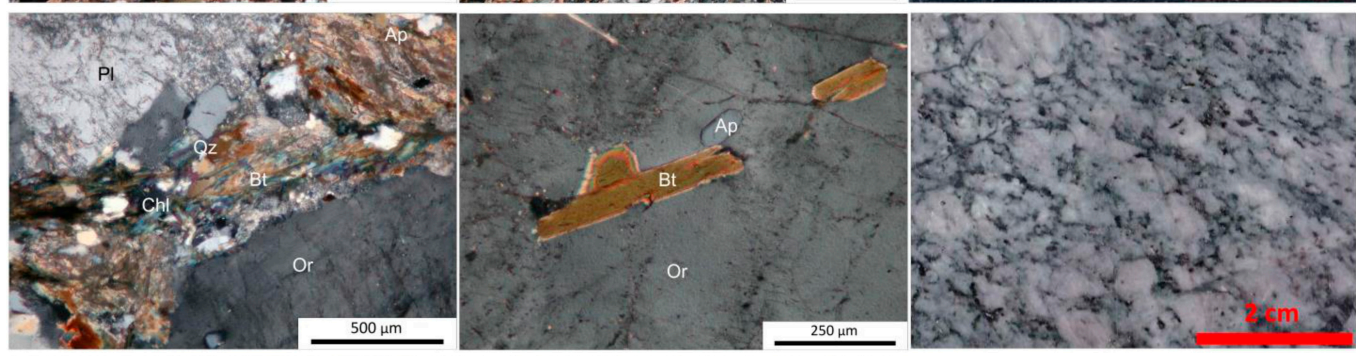

(e)
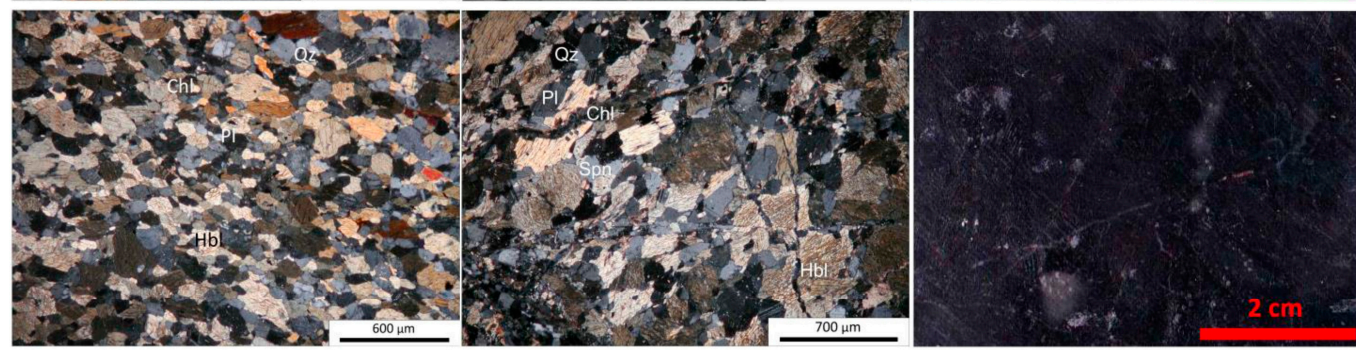

Figure 3. Representative photomicrographs and hand-specimen scale samples of host rocks. (a) Granite is predominated by quartz, plagioclase, and orthoclase; myrmekitic texture occurs in this rock; (b) Biotite alignment and myrmekitic texture appear in biotite gneiss; (c) Strong schistosity is indicated by biotite alignment in biotite schist; (d) feldspar porphyroblast deflect schistosity. Biotite and apatite inclusions were observed in feldspar porphyroblasts; and (e) Hornblende alignment occurs in amphibolitic schist. The left and center figures are the photomicrographs. The hand-specimen samples are shown in the figures to the right. Photomicrographs were taken under cross polarized light. Abbreviations: Ap (apatite), Bt (Biotite), Chl (chlorite), Hbl (hornblende), Or (orthoclase), $\mathrm{Pl}$ (plagioclase), Qz (quartz), and Spn (sphene).

Most granite and biotite gneiss have been altered. For the purposes of lithogeochemical analysis, the least-altered granite is distinguished from the altered granite on the basis of its loss on ignition 
(LOI) content. Altered granite is defined as granite whose LOI content is greater than $2.00 \%$. From the mineralogical perspective, plagioclase and biotite are altered to mica and chlorite, respectively.

The granite geochemistry is analyzed using the Fe-number $\left(\mathrm{Fe}^{*}\right)$ [18], the FeO-MgO ratio [19], the modified alkali-lime index (MALI) [18], and the aluminum saturation index (ASI) [20]. In terms of the tectonic setting, the granite geochemistry is analyzed using an $\mathrm{Nb}-\mathrm{Y}$ discriminant diagram proposed by Pearce et al. [21]. The same method is also applied to the biotite gneiss because it is thought to be derived from a granitic source.

Both the granite and biotite gneiss are categorized as magnesian arc calc-alkaline rocks, which follow the trend of the calcic and calc-alkaline borderline (Figure 4). The rocks can also be categorized as peraluminous because the ASI is greater than unity. In addition, the last diagram indicates that these rocks are emplaced in volcanic arc settings.

(a)

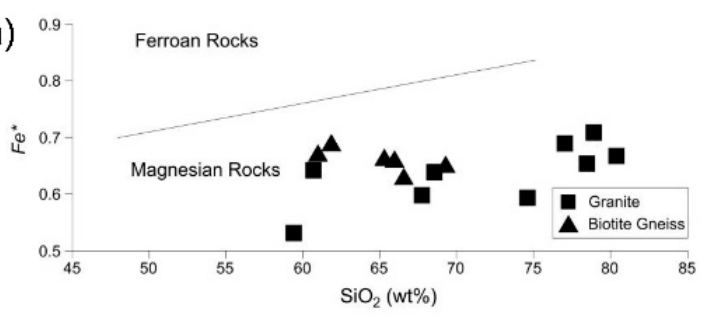

(c)

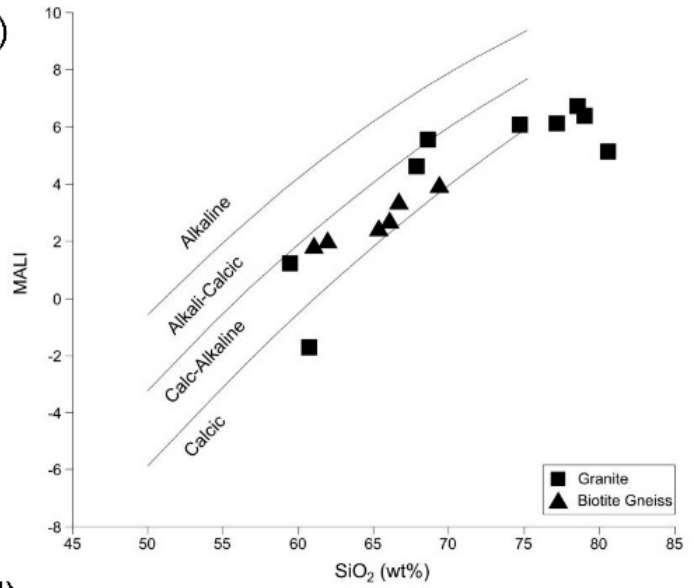

(d)

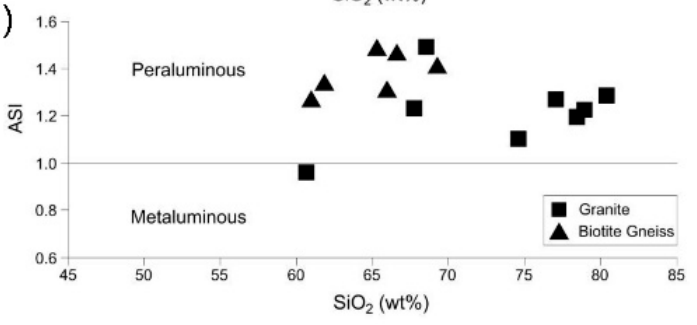

(b)

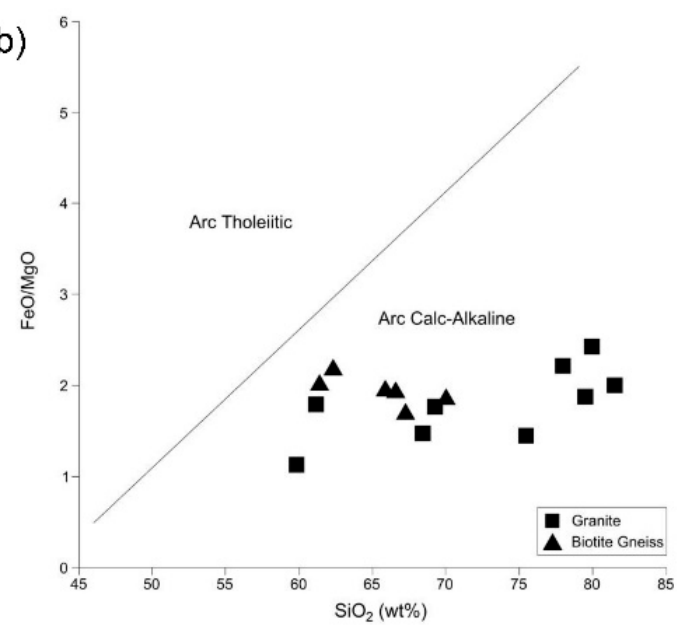

(e)

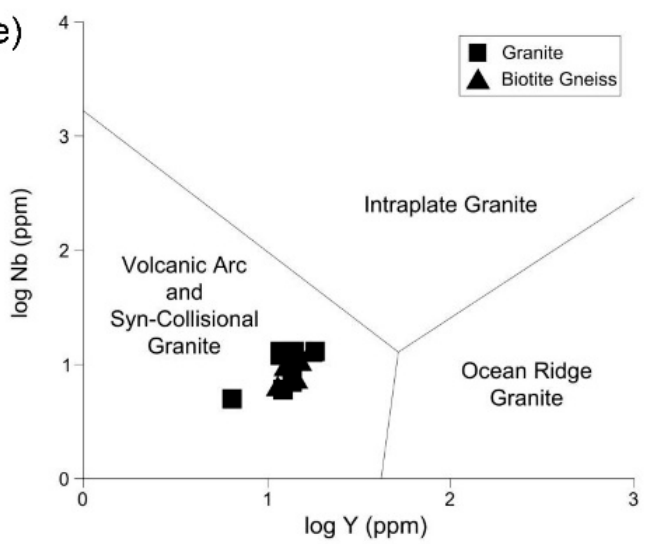

Figure 4. Geochemistry of the granite and biotite gneiss. Result plots of the rock composition on discriminant diagrams of (a) $\mathrm{Fe}^{*}-\mathrm{SiO}_{2}$ (after Frost et al. [18]); (b) $\mathrm{FeO} / \mathrm{MgO}-\mathrm{SiO}_{2}$ (after Miyashiro [19]); (c) MALI-SiO 2 (after Frost et al. [18]); (d) $\mathrm{ASI}_{-} \mathrm{SiO}_{2}$ (after Frost and Frost [20]); and (e) Nb-Y (after Pearce et al. [21]).

Referring to Table 1, the composition between the biotite schist and feldspar porphyroblastic biotite schist is not significantly different. Compared with the granite and biotite gneiss, these rocks have a higher abundance of $\mathrm{MgO}$ and $\mathrm{FeO}$. Significant differences are observed in the amphibolitic schist, which has lower $\mathrm{SiO}_{2}$ and higher $\mathrm{FeO}, \mathrm{MgO}$ and $\mathrm{CaO}$ contents. 
Table 1. Host rock compositions.

\begin{tabular}{|c|c|c|c|c|c|c|c|c|c|c|c|c|c|c|c|c|c|c|c|c|c|c|c|c|}
\hline \multirow{2}{*}{$\begin{array}{c}\text { Rock Type } \\
\text { Sample } \\
\end{array}$} & \multirow{2}{*}{ LOD } & \multicolumn{10}{|c|}{ Granite } & \multicolumn{5}{|c|}{ Biotite Gneiss } & \multicolumn{3}{|c|}{ Biotite Schist } & \multicolumn{4}{|c|}{$\begin{array}{c}\text { Feldspar Porphyroblastic } \\
\text { Biotite Schist }\end{array}$} & \multirow{2}{*}{$\begin{array}{c}\text { Amph } \\
\text { Schist }\end{array}$} \\
\hline & & 36-01 & $36-07$ & $36-08 *$ & $36-09$ * & $36-11$ * & $40-10$ * & $40-01$ & $40-04$ & $40-06$ & $40-16$ * & $36-13$ * & $36-14$ & $40-24$ & $40-26$ * & $40-29$ * & $36-20$ & $36-22$ & $40-47$ & $36-24$ & $40-36$ & $40-42$ & $40-45$ & \\
\hline $\mathrm{SiO}_{2}(\mathrm{wt} \%)$ & 0.02 & 60.7 & 74.6 & 78.5 & 78.9 & 69.3 & 80.4 & 59.4 & 67.7 & 68.5 & 77.0 & 61.8 & 61.0 & 65.3 & 66.6 & 66.0 & 63.4 & 63.7 & 65.3 & 56.6 & 66.0 & 63.2 & 66.2 & 50.0 \\
\hline $\mathrm{TiO}_{2}$ & 0.003 & 0.67 & 0.21 & 0.20 & 0.21 & 0.56 & 0.25 & 1.09 & 0.60 & 0.68 & 0.31 & 1.11 & 0.92 & 0.89 & 0.87 & 0.78 & 0.81 & 0.61 & 0.78 & 1.10 & 1.00 & 0.68 & 0.49 & 1.42 \\
\hline $\mathrm{Al}_{2} \mathrm{O}_{3}$ & 0.02 & 12.8 & 11.4 & 11.0 & 10.9 & 14.1 & 9.9 & 20.0 & 13.5 & 14.2 & 11.6 & 16.4 & 15.4 & 14.9 & 14.4 & 14.5 & 14.8 & 13.1 & 15.1 & 14.7 & 12.0 & 15.0 & 14.8 & 14.1 \\
\hline $\mathrm{FeO}$ & 0.004 & 3.52 & 1.11 & 1.14 & 1.28 & 3.25 & 1.18 & 3.35 & 2.86 & 3.31 & 1.67 & 5.38 & 5.11 & 4.59 & 3.95 & 4.27 & 6.25 & 4.22 & 5.63 & 5.97 & 4.95 & 3.31 & 2.92 & 10.33 \\
\hline $\mathrm{MnO}$ & 0.002 & 0.13 & 0.08 & 0.06 & 0.03 & 0.09 & 0.05 & 0.12 & 0.08 & 0.07 & 0.13 & 0.15 & 0.16 & 0.12 & 0.06 & 0.08 & 0.09 & 0.09 & 0.11 & 0.12 & 0.05 & 0.04 & 0.06 & 0.16 \\
\hline $\mathrm{MgO}$ & 0.03 & 2.0 & 0.8 & 0.6 & 0.5 & 1.8 & 0.6 & 3.0 & 1.9 & 1.9 & 0.8 & 2.5 & 2.6 & 2.4 & 2.4 & 2.2 & 4.2 & 3.6 & 3.8 & 4.7 & 3.8 & 3.6 & 2.4 & 8.9 \\
\hline $\mathrm{CaO}$ & 0.001 & 7.013 & 1.644 & 0.306 & 0.343 & 2.281 & 0.532 & 2.840 & 2.059 & 1.140 & 0.595 & 4.357 & 4.460 & 3.157 & 2.725 & 3.674 & 3.083 & 2.785 & 0.521 & 5.041 & 2.887 & 2.383 & 2.558 & 8.768 \\
\hline $\mathrm{Na}_{2} \mathrm{O}$ & 0.02 & 2.6 & 1.1 & 2.5 & 2.3 & 2.7 & 2.0 & 1.2 & 3.6 & 2.6 & 2.5 & 3.4 & 3.1 & 2.7 & 2.2 & 2.5 & 1.7 & 0.9 & 0.4 & 1.6 & 1.4 & 2.5 & 2.7 & 1.5 \\
\hline $\mathrm{K}_{2} \mathrm{O}$ & 0.003 & 2.66 & 6.64 & 4.59 & 4.40 & 3.46 & 3.67 & 2.82 & 3.08 & 4.14 & 4.25 & 2.86 & 3.12 & 2.84 & 3.83 & 3.79 & 2.48 & 5.89 & 4.09 & 5.74 & 3.70 & 4.74 & 4.61 & 0.84 \\
\hline $\mathrm{P}_{2} \mathrm{O}_{5}$ & 0.003 & 0.20 & 0.03 & 0.05 & 0.03 & 0.18 & 0.05 & 0.18 & 0.17 & 0.19 & 0.05 & 0.35 & 0.32 & 0.29 & 0.31 & 0.36 & 0.18 & 0.16 & 0.11 & 0.67 & 0.61 & 0.38 & 0.25 & 0.11 \\
\hline LOI & - & 6.66 & 2.06 & 0.74 & 0.85 & 1.85 & 1.13 & 5.41 & 3.40 & 2.52 & 0.99 & 1.33 & 2.97 & 2.26 & 1.89 & 1.09 & 2.82 & 4.01 & 3.96 & 2.89 & 2.81 & 3.12 & 2.35 & 3.44 \\
\hline Total & & 98.9 & 99.6 & 99.6 & 99.8 & 99.6 & 99.7 & 99.4 & 99.0 & 99.2 & 99.8 & 99.7 & 99.0 & 99.3 & 99.2 & 99.2 & 99.8 & 99.1 & 99.7 & 99.1 & 99.1 & 98.8 & 99.4 & 99.6 \\
\hline $\mathrm{S}(\mathrm{ppm})$ & 30 & 9250 & 2030 & 2910 & 1430 & 1630 & 1670 & 3360 & 8460 & 5970 & 510 & 910 & 7350 & 4420 & 5450 & 4540 & 520 & 7570 & 1920 & 1370 & 6170 & 6640 & 1280 & 2780 \\
\hline $\mathrm{V}$ & 15 & 70 & 30 & n.d. & 20 & 80 & 20 & 150 & 70 & 90 & 30 & 170 & 140 & 140 & n.d. & 110 & 150 & 120 & 160 & 170 & 140 & 100 & 70 & 370 \\
\hline $\mathrm{Cr}$ & 26 & n.d. & n.d. & n.d. & n.d. & n.d. & 30 & n.d. & n.d. & n.d. & n.d. & n.d. & n.d. & n.d. & 40 & 70 & 120 & 50 & 90 & 100 & 60 & 40 & n.d. & 310 \\
\hline Co & 100 & n.d. & n.d. & n.d. & n.d. & n.d. & n.d. & n.d. & n.d. & n.d. & n.d. & n.d. & n.d. & n.d. & n.d. & n.d. & n.d. & n.d. & n.d. & n.d. & n.d. & n.d. & n.d. & n.d. \\
\hline $\mathrm{Ni}$ & 15 & n.d. & n.d. & n.d. & n.d. & n.d. & 20 & n.d. & n.d. & n.d. & n.d. & n.d. & n.d. & n.d. & 20 & 30 & 60 & 30 & 60 & 40 & 40 & 30 & 20 & 80 \\
\hline $\mathrm{Cu}$ & 5 & 5 & 6 & n.d. & 11 & n.d. & 17 & 6 & n.d. & n.d. & n.d. & 9 & 8 & 8 & 79 & 106 & 5 & 33 & 42 & 39 & 103 & 19 & 45 & 34 \\
\hline $\mathrm{Zn}$ & 20 & 30 & 80 & 20 & n.d. & 30 & 40 & 60 & 50 & 40 & 90 & 60 & 70 & 70 & 30 & 70 & 50 & 60 & 60 & 80 & 30 & 50 & 60 & 60 \\
\hline $\mathrm{Pb}$ & 15 & n.d. & 40 & n.d. & n.d. & 15 & n.d. & n.d. & n.d. & n.d. & n.d. & n.d. & 15 & n.d. & n.d. & n.d. & n.d. & 15 & 15 & 20 & n.d. & 30 & 50 & n.d. \\
\hline As & 2 & n.d. & 6 & 27 & 6 & n.d. & 22 & n.d. & 6 & 91 & n.d. & n.d. & 19 & 32 & 93 & 41 & 3 & 74 & 60 & 4 & 192 & 278 & 17 & 93 \\
\hline Mo & 30 & n.d. & n.d. & n.d. & n.d. & n.d. & n.d. & n.d. & n.d. & n.d. & n.d. & n.d. & n.d. & n.d. & n.d. & n.d. & n.d. & n.d. & n.d. & n.d. & n.d. & n.d. & n.d. & n.d. \\
\hline $\mathrm{Rb}$ & 3 & 79 & 295 & 139 & 131 & 96 & 108 & 102 & 95 & 158 & 127 & 116 & 126 & 118 & 124 & 116 & 111 & 280 & 216 & 182 & 183 & 169 & 138 & 46 \\
\hline $\mathrm{Sr}$ & 3 & 372 & 153 & 81 & 108 & 457 & 121 & 235 & 318 & 316 & 116 & 665 & 685 & 553 & 475 & 607 & 288 & 235 & 24 & 1421 & 498 & 984 & 980 & 190 \\
\hline $\mathrm{Ba}$ & 80 & 900 & 830 & 450 & 400 & 1660 & 150 & 1200 & 1130 & 1390 & 790 & 1050 & 1000 & 890 & 1380 & 1620 & 490 & 720 & 250 & 4870 & 780 & 3130 & 3160 & 110 \\
\hline $\mathrm{Y}$ & 2 & 42 & 24 & 29 & 11 & 23 & 25 & 30 & 24 & 29 & 29 & 39 & 30 & 26 & 31 & 33 & 38 & 23 & 28 & 55 & 43 & 33 & 27 & 35 \\
\hline $\mathrm{Zr}$ & 4 & 269 & 105 & 188 & 76 & 244 & 110 & 273 & 262 & 286 & 169 & 401 & 333 & 336 & 303 & 328 & 171 & 131 & 149 & 444 & 406 & 309 & 246 & 87 \\
\hline $\mathrm{Nb}$ & 3 & 13 & 13 & 7 & 5 & 6 & 6 & 13 & 12 & 13 & 8 & 12 & 10 & 9 & 7 & 10 & 10 & 6 & 9 & 19 & 16 & 13 & 13 & n.d. \\
\hline
\end{tabular}




\subsection{Hydrothermal Alteration}

The hydrothermal alteration in the RRZ have a zonation that is delineated because of the proximity of the main fluid conduit. The zoned hydrothermal alteration starts from an inner propylitic zone composed of chlorite, illite, chlorite/smectite, illite/smectite, and calcite, and it is followed by a high-T propylitic zone consisting of chlorite, epidote, calcite, illite/smectite, and smectite. The outermost zone, a low-T propylitic zone, is composed of chlorite, illite/smectite and smectite. At the surface, the hydrothermal alteration consists of the low-T propylitic zone. Typical clay mineral diffraction patterns and hydrothermal alteration zoning are identified based on core and outcrop sample analyses, and they are illustrated in Figures 5 and 6, respectively.

(a)

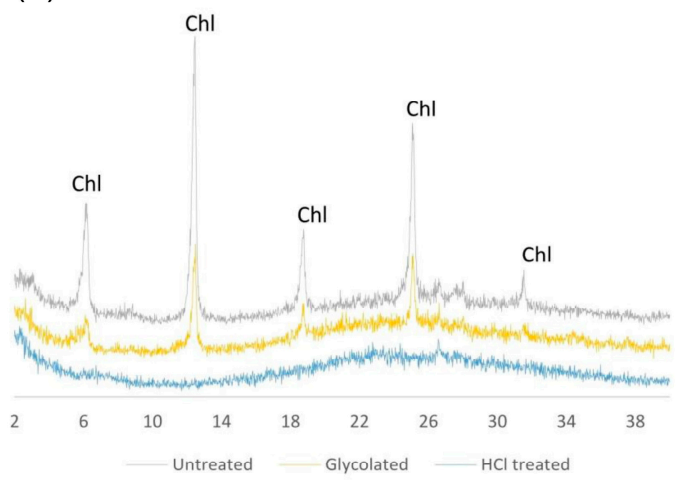

(c)

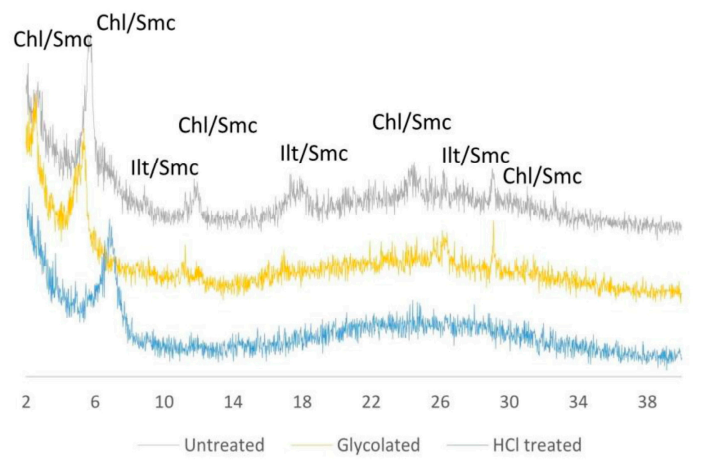

(b)

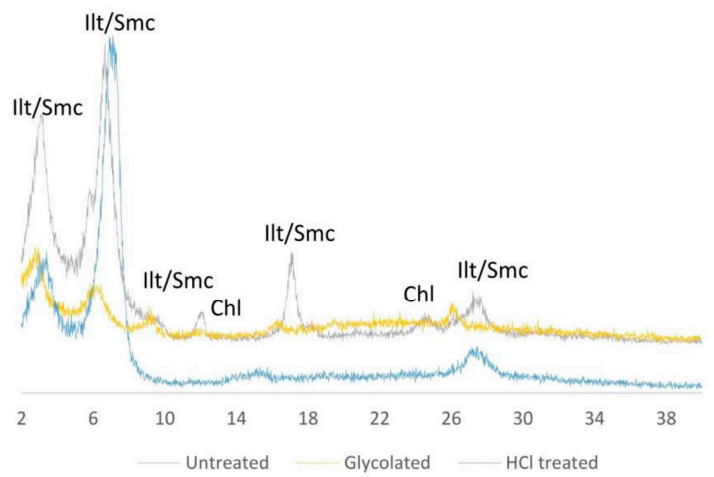

(d)

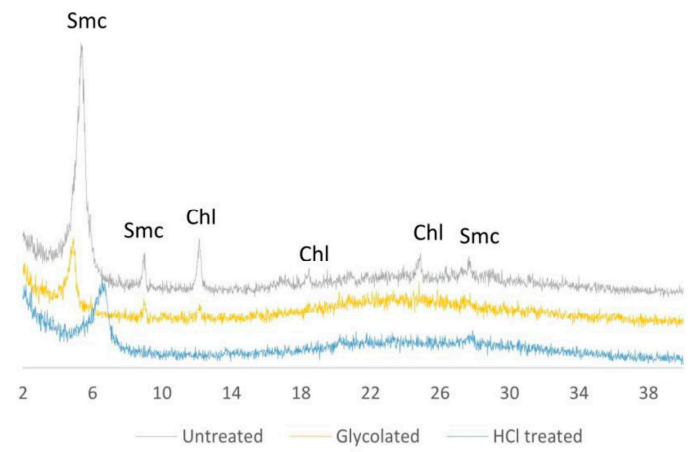

Figure 5. Typical clay mineral diffraction patterns: (a) chlorite; (b) illite/smectite; (c) chlorite/smectite, and (d) smectite. Chlorite peaks disappear after being treated by $\mathrm{HCl}$ and exhibit no response after being treated by ethylene glycol. Illite/smectite, chlorite/smectite, and smectite peaks shift to higher d-values after being treated by ethylene glycol, indicating mineral swelling. These minerals show different responses after being treated by $\mathrm{HCl}$ : While illite/smectite peaks do not change, chlorite/smectite and smectite peaks shift to lower d-values, indicating loss of chlorite and water in smectite structure. 

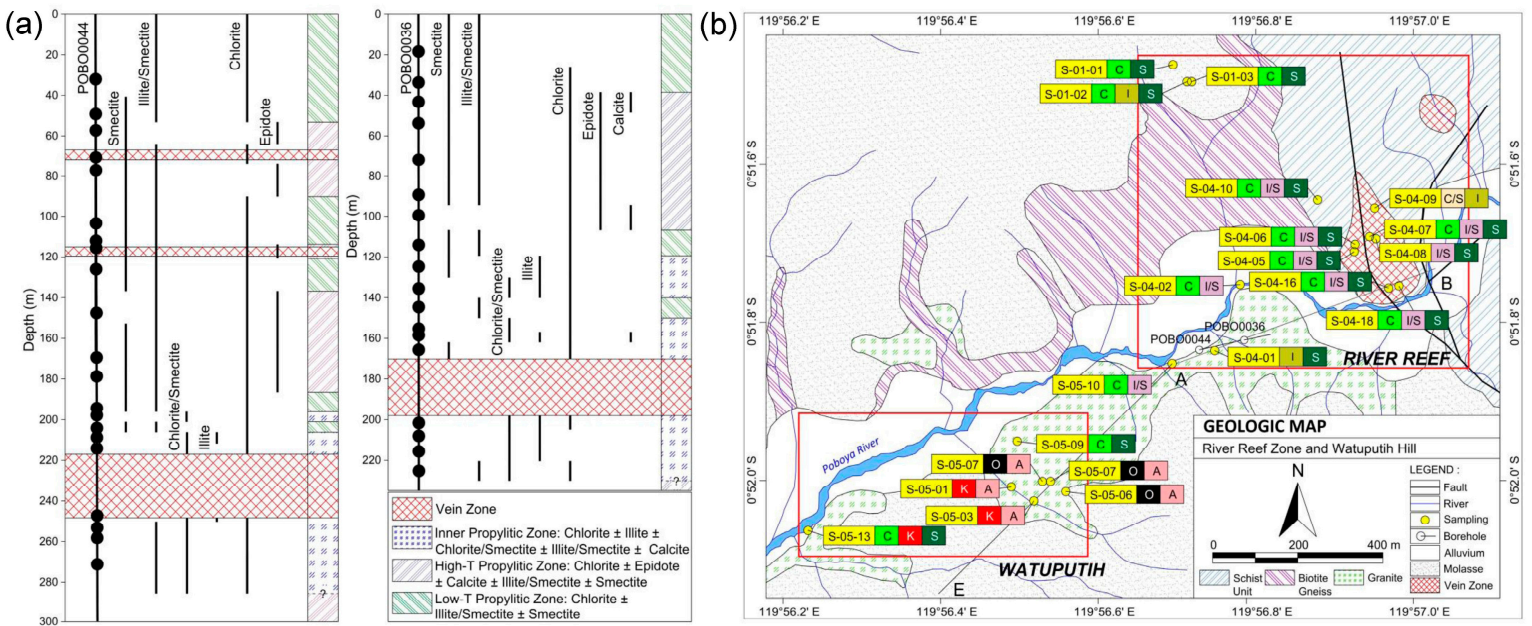

Figure 6. (a) Subsurface zoned hydrothermal alterations of the RRZ. The black dots indicate the position of samples relative to the drilling depth of boreholes POBO0044 and POBO0036. Occurrence of alteration minerals is represented by black bars; (b) Hydrothermal alteration at the surface of the River Reef Zone and Watuputih Hill. Abbreviations: A (alunite), C (chlorite), C/S (chlorite/smectite), I (illite), I/S (illite/smectite), K (kaolinite), O (opal), and S (smectite).

Under the microscope, quartz is observed to predominantly replace rock-forming minerals at the contact between veins and their surrounding rocks (Figure 7a). Chlorite and chlorite/smectite appear to replace biotite and hornblende, respectively (Figure $7 \mathrm{~b}$ ). Plagioclase is altered by epidote and calcite (Figure 7c). The mica group minerals, such as illite, illite/smectite, and smectite, replace feldspar (Figure 7d).

(a)

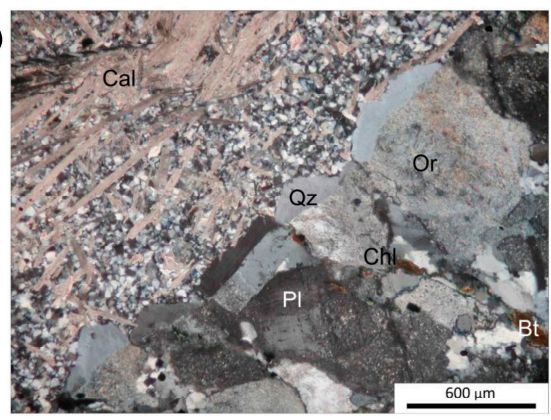

(c)

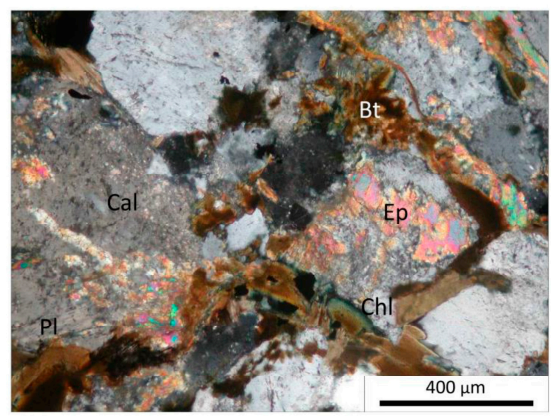

(b)

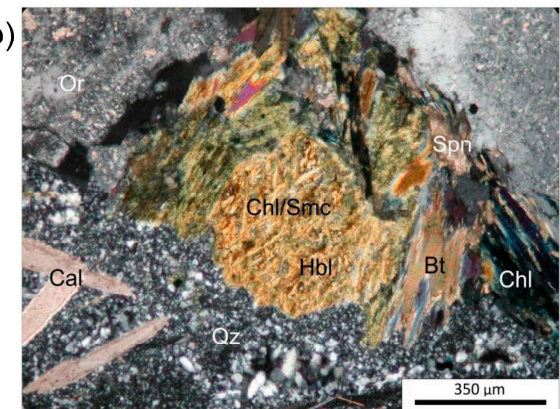

(d)

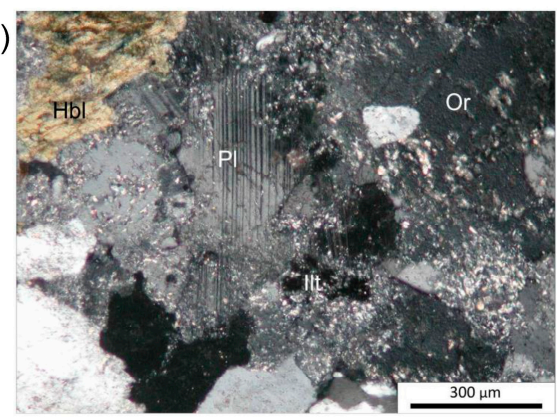

Figure 7. Representative photomicrographs of the (a) quartz replacement at the contacts between veins and wall rocks; (b) hornblende alterations to chlorite/smectite and biotite alterations to chlorite; (c) epidote and calcite occurrences after plagioclase; and (d) mica group minerals replacing feldspar. Abbreviations: Bt (biotite), Cal (calcite), Chl (chlorite), Chl/Smc (chlorite/smectite), Ep (epidote), $\mathrm{Hbl}$ (hornblende), Ilt (illite), Or (orthoclase), Pl (plagioclase), Qz (quartz), and Spn (sphene). 
In $\mathrm{WPH}$, hydrothermal alteration mineral assemblages at the peak and the hillside are distinct. An assemblage of opal, quartz, and alunite occurs at the peak of the hill (Figure 8a). Conversely, the hillside is composed of the assemblage quartz, kaolinite, alunite, pyrite, goethite, and jarosite (Figure 8b). As the elevation decreases, kaolinite coexists with smectite (Figure 8c). A contrast between the peak and the hillside is also observed from the geochemistry data of the rocks. The rocks at the peak of the hill contain a substantially higher $\mathrm{SiO}_{2}$ content and lower $\mathrm{Al}_{2} \mathrm{O}_{3}, \mathrm{FeO}, \mathrm{K}_{2} \mathrm{O}$, and $\mathrm{S}$ contents than the hillside (Table 2). The geochemical behavior of rocks at the hill is consistent with the distinct alteration mineral assemblages. At the peak of $\mathrm{WPH}$, opal-predominant rocks yielded extremely high $\mathrm{SiO}_{2}$ and lower $\mathrm{Al}_{2} \mathrm{O}_{3}, \mathrm{FeO}, \mathrm{K}_{2} \mathrm{O}$, and $\mathrm{S}$ contents. In contrast, the presence of alunite and kaolinite is indicated by higher $\mathrm{Al}_{2} \mathrm{O}_{3}$ and $\mathrm{K}_{2} \mathrm{O}$ contents at the hillside. Higher $\mathrm{FeO}$ and $\mathrm{S}$ contents reflect pyrite, jarosite, and goethite assemblages.

(a)

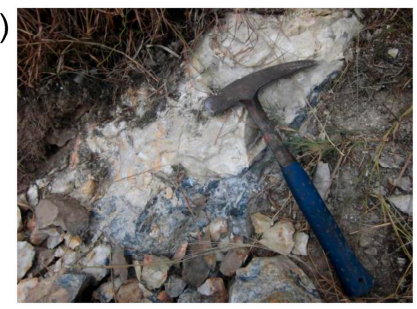

(b)

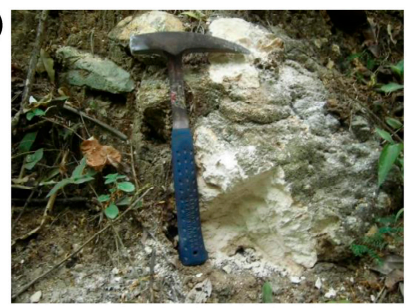

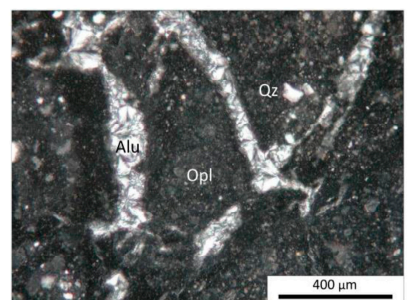

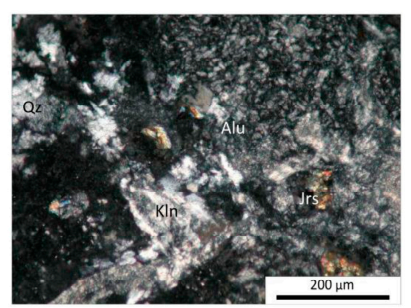

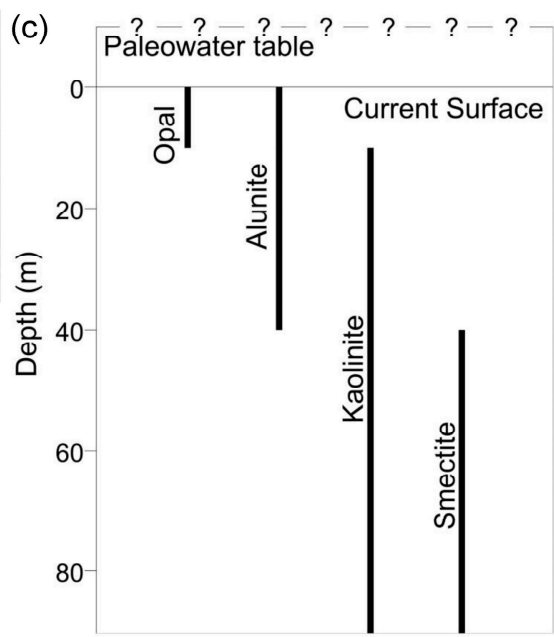

Figure 8. Representative outcrops and photomicrographs of the hydrothermal alterations at WPH. (a) Massive opal and alunite with quartz clasts in the peak of WPH; (b) Powdery kaolinite coexists with quartz and alunite in the hillside of WPH. Jarosite occurs as pyrite replacement; (c) Vertically zoned hydrothermal alteration at Watuputih Hill. Occurrence of alteration minerals is represented by black bars. Abbreviations: Alu (alunite), Jrs (jarosite), Kln (kaolinite), Opl (opal), and Qz (quartz).

Table 2. Composition of the altered rocks in WPH.

\begin{tabular}{|c|c|c|c|c|c|c|c|}
\hline \multirow{2}{*}{$\begin{array}{c}\text { Location } \\
\text { Sample }\end{array}$} & \multirow{2}{*}{ LOD } & \multicolumn{3}{|c|}{ Peak } & \multicolumn{3}{|c|}{ Hillside } \\
\hline & & 06-01 & 07-01 & 08-01 & 01-01 & 03-01 & 03-02 \\
\hline $\mathrm{SiO}_{2}(\mathrm{wt} \%)$ & 0.02 & 89.5 & 96.4 & 91.3 & 55.4 & 62.5 & 56.3 \\
\hline $\mathrm{TiO}_{2}$ & 0.003 & 1.14 & 0.25 & 3.4 & 0.16 & 0.77 & 0.41 \\
\hline $\mathrm{Al}_{2} \mathrm{O}_{3}$ & 0.02 & 2.7 & 0.4 & 0.8 & 16.6 & 16.3 & 14.7 \\
\hline $\mathrm{FeO}$ & 0.004 & 0.53 & 0.41 & 0.56 & 0.58 & 1.23 & 2.5 \\
\hline $\mathrm{MnO}$ & 0.002 & n.d. & n.d. & n.d. & n.d. & n.d. & n.d. \\
\hline $\mathrm{MgO}$ & 0.03 & 0.3 & 0.3 & 0.3 & 0.3 & 0.8 & 0.3 \\
\hline $\mathrm{CaO}$ & 0.001 & 0.253 & 0.090 & 0.171 & 0.105 & 0.208 & 0.082 \\
\hline $\mathrm{Na}_{2} \mathrm{O}$ & 0.02 & 0.5 & 0.3 & 0.4 & 0.4 & 1.1 & 0.4 \\
\hline $\mathrm{K}_{2} \mathrm{O}$ & 0.003 & 0.36 & 0.03 & 0.05 & 2.57 & 2.82 & 2.45 \\
\hline $\mathrm{P}_{2} \mathrm{O}_{5}$ & 0.003 & 0.33 & n.d. & 0.07 & 0.08 & 0.15 & 0.05 \\
\hline LOI & - & 3.22 & 1.83 & 2.88 & 18.03 & 11.34 & 17.15 \\
\hline Total & & 98.8 & 100 & 99.9 & 94.2 & 97.2 & 94.3 \\
\hline$S$ (ppm) & 30 & 9700 & 250 & 530 & 56210 & 26510 & 55740 \\
\hline $\mathrm{V}$ & 15 & 60 & 20 & 180 & 50 & 110 & 60 \\
\hline $\mathrm{Cr}$ & 26 & n.d. & n.d. & n.d. & n.d. & n.d. & n.d. \\
\hline $\mathrm{Co}$ & 100 & n.d. & n.d. & n.d. & n.d. & n.d. & n.d. \\
\hline
\end{tabular}


Table 2. Cont.

\begin{tabular}{|c|c|c|c|c|c|c|c|}
\hline \multirow{2}{*}{$\begin{array}{c}\text { Location } \\
\text { Sample }\end{array}$} & \multirow{2}{*}{ LOD } & \multicolumn{3}{|c|}{ Peak } & \multicolumn{3}{|c|}{ Hillside } \\
\hline & & 06-01 & 07-01 & 08-01 & 01-01 & 03-01 & 03-02 \\
\hline $\mathrm{Ni}$ & 15 & n.d. & n.d. & n.d. & n.d. & n.d. & n.d. \\
\hline $\mathrm{Cu}$ & 5 & n.d. & n.d. & n.d. & n.d. & 7 & 7 \\
\hline $\mathrm{Zn}$ & 20 & n.d. & n.d. & n.d. & n.d. & n.d. & n.d. \\
\hline $\mathrm{Pb}$ & 15 & 50 & n.d. & n.d. & 30 & n.d. & n.d. \\
\hline As & 2 & n.d. & 5 & 3 & n.d. & n.d. & n.d. \\
\hline Mo & 30 & n.d. & n.d. & n.d. & n.d. & n.d. & n.d. \\
\hline $\mathrm{Rb}$ & 3 & n.d. & n.d. & n.d. & 24 & 108 & 22 \\
\hline $\mathrm{Sr}$ & 3 & 708 & n.d. & 89 & 176 & 191 & 92 \\
\hline $\mathrm{Ba}$ & 80 & 870 & n.d. & 170 & 1280 & 1050 & 830 \\
\hline $\mathrm{Y}$ & 2 & 5 & 3 & 4 & 4 & 22 & 4 \\
\hline $\mathrm{Zr}$ & 4 & 321 & 155 & 286 & 108 & 264 & 246 \\
\hline $\mathrm{Nb}$ & 3 & 20 & 6 & 21 & 6 & 11 & 6 \\
\hline
\end{tabular}

\section{Discussion}

In the RRZ and WPH, granite is characterized by several textures: holocrystalline, interlocking, phaneritic, and myrmekitic textures. Holocrystalline and interlocking textures indicate slow crystallization from magma. A plutonic environment is indicated by the phaneritic texture of the rocks. The simultaneous crystallization of quartz and feldspar is implied by the presence of a myrmekitic texture [22]. A sudden loss of $\mathrm{H}_{2} \mathrm{O}$ increases the melting point of the minerals and leads to rapid simultaneous crystallization [23]. An intergrowth texture occurred under this condition because independent crystals could not have formed within the allotted time span.

Biotite gneiss is characterized by the abundance of quartz, feldspar, and biotite within the rocks. The abundant amount of quartz and feldspar indicates a quartzo-feldspathic protolith [24]. The myrmekitic texture narrows down the protolith to a granitic origin, consistent with the previously proposed idea that the gneiss unit in the PMC is derived from orthogneiss of Gondwana affinity $[15,25]$.

As mentioned above, the granite and biotite gneiss in the RRZ can be classified as magnesian rocks. This result implies that the rocks underwent a small $\mathrm{FeO}$ enrichment relative to $\mathrm{MgO}$ during the silica enrichment of the rocks [26]. Miyashiro [19] classified that rocks that do not undergo FeO enrichment are calc-alkaline rocks. The composition of the rocks, which plots on the calcic and calc-alkaline borderline, have common geochemical characteristics with magnesian granitic rocks [18].

Evidence is also provided for a peraluminous rock classification. Calc-alkaline magnesian rocks generally have a peraluminous composition [18]. ASI values greater than unity indicate that the rocks have an excessive amount of $\mathrm{Al}$ in the feldspar minerals. The excessive amount of $\mathrm{Al}$ has to be buffered by other aluminous phase minerals. In these rocks, the presence of biotite as the buffer mineral suggests that the rocks can be further classified as weakly peraluminous granitic rocks.

Frost et al. [27] and Frost and Frost [20] proposed that magnesian granitic rocks are related to relatively hydrous and oxidizing magmas. These features are consistent with the magmas derived from subduction-related settings. Because the granite and biotite gneiss in the RRZ are magnesian rocks, this idea is consistent with the plotting results on the $\mathrm{Nb}-\mathrm{Y}$ discrimination diagram, which indicates volcanic arc settings.

Compared with biotite gneiss, which is derived from granitic rocks, the schist unit was formed by the regional metamorphism of pelitic and psammitic sediments [25]. This idea is supported by the abundance of quartz and feldspar in the rock. The metamorphism event can also be deduced from the rock fabric dominated by flattened quartz, feldspar, biotite, and hornblende in one predominant direction [23]. Asymmetrical crenulations of the fabric that appear in the deeper part are characterized by high angle limbs. Pressure may have dissolved the quartz and reprecipitated it in the hinge areas. This structure may be generated because of accelerated silica transfer during metamorphic 
segregation [28]. The distinct $\mathrm{SiO}_{2}, \mathrm{FeO}, \mathrm{MgO}$, and $\mathrm{CaO}$ contents of the amphibolitic schist reflect the abundant plagioclase and amphibole contents compared with that of other rocks in this zone.

The presence of hydrothermal alteration in the RRZ is evidence that a hydrothermal fluid once flowed through the open spaces generated in this zone. Hydrothermal alteration is considered because of the fluid-rock interactions [29]. As explained above, K-feldspar is one of the most predominant rock-forming minerals identified within the host rocks in the RRZ. Close to the primary fluid conduit, $\mathrm{H}^{+}$ions transported by the hydrothermal fluid alter feldspar to form illite and quartz. Similarly, the ions come into contact with biotite, which is altered to chlorite. These reactions also release $\mathrm{K}^{+}$ions into the remaining fluid as shown by reactions 1 and 2:

$$
\begin{array}{clll}
\mathrm{KAlSi}_{3} \mathrm{O}_{8}+2 \mathrm{H}^{+}= & \mathrm{KAl}_{3} \mathrm{Si}_{3} \mathrm{O}_{10}(\mathrm{OH})_{2}+6 \mathrm{SiO}_{2}+2 \mathrm{~K}^{+} & \\
\text {K-Feldspar } & \text { Illite } & \text { Quartz } \\
2 \mathrm{KMg}_{3} \mathrm{AlSi}_{3} \mathrm{O}_{10}(\mathrm{OH})_{2}+4 \mathrm{H}^{+}= & \mathrm{Mg}_{5} \mathrm{Al}_{2} \mathrm{Si}_{3} \mathrm{O}_{10}(\mathrm{OH})_{8}+2 \mathrm{~K}^{+}+\mathrm{Mg}^{2+}+3 \mathrm{SiO}_{2} \\
\text { Biotite } & \text { Chlorite } & \text { Quartz }
\end{array}
$$

In the high-T propylitic zone, epidote is present because of the reaction between calcic-plagioclase and $\mathrm{Ca}^{2+}$ ions in the hydrothermal fluid [30]. In the deeper zone, gas loss causes $\mathrm{CO}_{2}$ to ascend via a different path along with the rest of the hydrothermal fluid. The gas is subsequently absorbed by groundwater and forms $\mathrm{CO}_{2}$-rich steam-heated water. In the water, the absorbed $\mathrm{CO}_{2}$ forms $\mathrm{H}_{2} \mathrm{CO}_{3}$, which is further dissociated to $\mathrm{HCO}^{3-}$ and $\mathrm{H}^{+}$ions [31]. This zone is subsequently influenced by the waning of the hydrothermal fluid. As the inferred heat source cools, the pressure of the hydrothermal fluid decreases, which triggers the $\mathrm{CO}_{2}$-rich steam-heated water to descend [32]. The water interaction with calcic-plagioclase in the rocks promotes the precipitation of calcite and clay minerals [33]. Smectite, illite/smectite, and calcite overprint the alteration minerals at the low- $\mathrm{T}$, high-T, and inner propylitic zones. The reactions lead to the precipitation of epidote, calcite, and clay minerals as shown in reactions 3 to 7 :

$$
\begin{aligned}
& 3 \mathrm{CaAl}_{2} \mathrm{~S}_{\mathrm{i} 2} \mathrm{O}_{8}+\mathrm{Ca}^{2+}+2 \mathrm{H}_{2} \mathrm{O}=2 \mathrm{CaAl}_{3} \mathrm{Si}_{3} \mathrm{O}_{12}(\mathrm{OH})+2 \mathrm{H}^{+} \\
& \text {Ca-Plagioclase Epidote } \\
& \mathrm{CO}_{2}+\mathrm{H}_{2} \mathrm{O}=\mathrm{H}_{2} \mathrm{CO}_{3} \\
& \mathrm{H}_{2} \mathrm{CO}_{3}=\mathrm{HCO}_{3}{ }^{-}+\mathrm{H}^{+} \\
& \mathrm{CaCO}_{3}+\mathrm{H}_{2} \mathrm{CO}_{3}=\mathrm{Ca}^{2+}+2 \mathrm{HCO}_{3}{ }^{-} \\
& \text {Calcite } \\
& \mathrm{CaAl}_{2} \mathrm{Si}_{2} \mathrm{O}_{8}+\mathrm{CO}_{2}=\mathrm{CaCO}_{3}+\text { Clay } \\
& \text { Ca-Plagioclase Calcite }
\end{aligned}
$$

As summarized by White and Hedenquist [34], the presence of alteration mineral assemblages in the RRZ represented by the inner, low-T, and high- $\mathrm{T}$ propylitic zones suggests that the hydrothermal fluid has a near-neutral $\mathrm{pH}$ (Figure 9). 


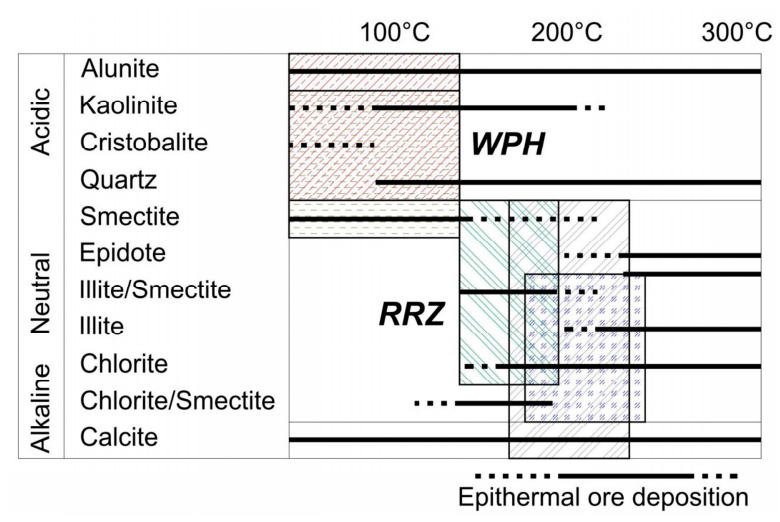

Figure 9. Relationship between the hydrothermal alteration assemblages of the River Reef Zone and the Watuputih Hill according to the $\mathrm{pH}$ of the hydrothermal fluid (modified after [34]). Hydrothermal alteration in the RRZ and WPH was the product of rock interactions with near neutral and acidic fluids, respectively. The legend follows Figure 6a.

Compared with the alteration of mineral assemblages in the RRZ, the hydrothermal alteration in WPH results in an assemblage of opal, quartz, and alunite at the peak of the hill and an assemblage of quartz, kaolinite, alunite, pyrite, goethite, and jarosite at the hillside. The distinct rock geochemistry reflects the difference of the alteration mineral assemblages. Following the classification of advanced argillic zones proposed by Simmons et al. [35], three possibilities were considered for interpreting the occurrence of advanced argillic alteration mineral assemblages occurring in WPH. The first possibility, an advanced argillic zone related to a high-sulfidation epithermal mineralization (hypogene advanced argillic), was ruled out because of a lack of vuggy textures in the silica body, barren rock, fine-grained alunite, and opal extensively present in WPH. The second possibility, an advanced argillic zone related to low-sulfidation epithermal mineralization (steam-heated advanced argillic), is supported by the presence of opal and fine-grained alunite in WPH peak. The alteration mineral assemblage is dominated more by kaolinite toward the hillside and by smectite in the foothill (Figure 8c), suggesting steam-heated water neutralization. In this regard, we considered that the steam-heated advanced argillic zone in WPH represented near-surface alteration related to the low-sulfidation deposit in RRZ. However, this possibility was weak, as WPH is located approximately $500 \mathrm{~m}$ to the southwest of RRZ. To address this issue, the third possibility was proposed of WPH as near-surface alteration of another low-sulfidation mineralization system (Figure 10).

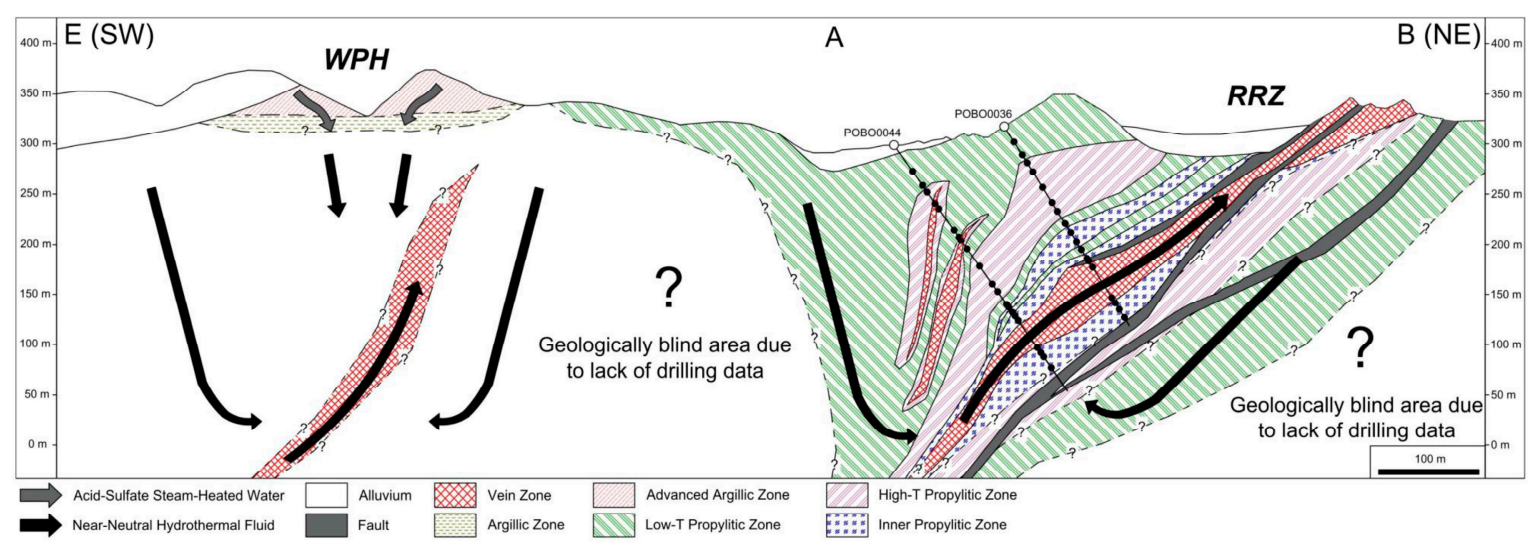

Figure 10. Alteration descriptive model in the RRZ and the WPH. In the RRZ, hydrothermal alteration is zoned from inner to high-T and low-T propylitic zones as a consequence of water-rock interaction. Acidic fluid in the WPH is neutralized, resulting in advanced argillic and argillic zones. Another inferred mineralization system is depicted. The model is drawn on section E-A-B shown in Figure 2. 
The acid-sulfate steam-heated water is a product of $\mathrm{H}_{2} \mathrm{~S}$ absorption by groundwater in the near-surface environment [31]. Because of the gas exsolution occurring at depth, the gas ascends and comes into contact with the atmospheric environment. The gas is subsequently oxidized to form $\mathrm{H}_{2} \mathrm{SO}_{4}$, which is further dissociated to $\mathrm{H}^{+}$and $\mathrm{SO}_{4}{ }^{2-}$ ions. The water interacts with the surrounding rocks and alters $\mathrm{K}$-feldspar to alunite, which is considered a key mineral in the presence of $\mathrm{SO}_{4}{ }^{2-}$ [12]. In addition to alunite, the intense leaching of the host rocks by the water leads to the precipitation of $\mathrm{SiO}_{2}$ residue, thereby causing the deposit to be typically siliceous. The reactions that produce the assemblage of opal, quartz, and alunite at the peak of the WPH are shown below:

$$
\begin{array}{ccc}
\mathrm{H}_{2} \mathrm{~S}+ & 2 \mathrm{O}_{2}=\mathrm{H}_{2} \mathrm{SO}_{4} \\
3 \mathrm{KAlSi}_{3} \mathrm{O}_{8}+6 \mathrm{H}^{+}+2 \mathrm{SO}_{4}{ }^{2-}= & \mathrm{KAl}_{3}\left(\mathrm{SO}_{4}\right)_{2}(\mathrm{OH})_{6}+9 \mathrm{SiO}_{2}+2 \mathrm{~K}^{+} \\
\text {K-Feldspar } & \text { Alunite } & \text { Quartz }
\end{array}
$$

As the water flow descends, the water $\mathrm{pH}$ increases because of fluid-rock interactions. The $\mathrm{pH}$ increase suggested that the alteration assemblage is vertically zoned from alunite at the top to kaolinite and smectite at the bottom of the hill [32]. The coexistence of kaolinite and smectite as well as the lack of alunite at the bottom of the hill may suggest the presence of an argillic zone beneath the hill. The occurrence of these zones marks the position of the paleowater table.

Regarding the hillside of $\mathrm{WPH}$, the alteration mineral assemblage reflects a supergene advance argillic zone. This interpretation was grounded in the occurrence of jarosite and goethite after pyrite, reflecting oxidation of pyrite post-dating hydrothermal activity in WPH [35].

\section{Conclusions}

The gold mineralization in the RRZ is hosted within granite, biotite gneiss, and schist units composed of biotite schist intercalated by feldspar porphyroblastic biotite schist and amphibolitic schist. The rocks are emplaced within volcanic arc settings. The rock-forming minerals are altered to form a zoned hydrothermal alteration consisting of inner, high- $T$, and low-T propylitic zones. The near-neutral hydrothermal fluid is responsible for the alteration processes in the RRZ. As this zoned hydrothermal alteration in the RRZ has now been understood, this alteration distribution pattern can be used as a guide for exploration of gold mineralization in other vein zones (HRZ-1 and HRZ-2).

Granite in WPH is severely altered to the advanced argillic alteration zone formed in an acidic environment. The argillic alteration zone occurs at the bottom portion of the hill, suggesting fluid neutralization. The presence of the zones marks the paleowater table position and oxidation processes postdating the hydrothermal activity. The distant position of WPH from the RRZ indicates the possibility of another mineralization system beneath the hill. Additionally, the zoned hydrothermal alteration documented in RRZ, and its extension in WPH, is consistent with the characteristics of hydrothermal alteration zones in low-sulfidation epithermal deposits.

Acknowledgments: The authors thank the management and staff of PT Bumi Resources Minerals, Tbk. for supporting the fieldwork and providing supplementary information concerning this research. We are also immensely grateful to Thomas David Tindell and the members of the Laboratory of Economic Geology, Kyushu University for providing invaluable discussions and assistance during the sample analysis and interpretation. The authors thank the academic editor and three anonymous reviewers for their valuable comments that helped improve the clarity of the manuscript. Our deepest gratitude is extended to the Advanced Graduate Program in Global Strategy for Green Asia for providing funding support of this research.

Author Contributions: Syafrizal and Tomy Alvin Rivai developed the concepts, designed this study and carried out the fieldworks with guidance of Damar Kusumanto, Syafrizal, Tomy Alvin Rivai and Arie Naftali Hawu Hede wrote the manuscript with contribution on interpretation and discussion of the results from Kotaro Yonezu and Koichiro Watanabe. Tomy Alvin Rivai collected the data and conducted the laboratory analysis. All authors read and commented on the manuscript.

Conflicts of Interest: The authors declare no conflict of interest. 


\section{References}

1. Van Leeuwen, T.M.; Pieters, P.E. Mineral deposits of sulawesi. In The Sulawesi Mineral Resources 2011 Seminar MGEI-IAGI; Masyarakat Geologi Ekonomi Indonesia (MGEI)-Ikatan Ahli Geologi Indonesia (IAGI): Manado, Indonesia, 2011; pp. 1-130.

2. Wajdi, M.F.; Santoso, B.; Kusumanto, D.; Digdowirogo, S. Metamorphic Hosted Low Sulphidation Epithermal Gold System At Poboya, Central Sulawesi: A General Descriptive Review. Maj. Geol. Indones. 2012, 27, 131-141.

3. Carlile, J.C.; Mitchell, A.H.G. Magmatic Arcs and Associated Gold and Copper Mineralization in Indonesia. J. Geochem. Explor. 1994, 50, 91-142. [CrossRef]

4. Garwin, S.; Hall, R.; Watanabe, Y. Tectonic setting, geology, and gold and copper mineralization in cenozoic magmatic arcs of southeast asia and the west pacific. In Economic Geology 100th Anniversary Volume; Hedenquist, J.W., Thompson, J.F.H., Goldfarb, R.J., Richards, J.P., Eds.; Society of Economic Geologists: Littleton, CO, USA, 2005; pp. 891-930.

5. Kavalieris, I.; Walshe, J.L.; Halley, S.; Harrold, B.P. Dome-Related Gold Mineralization in the Pani Volcanic Complex, North Sulawesi, Indonesia; A Study of Geologic Relations, Fluid Inclusions, and Chlorite Compositions. Econ. Geol. 1990, 85. [CrossRef]

6. Perelló, J. Geology, Porphyry $\mathrm{Cu}-\mathrm{Au}$, and Epithermal $\mathrm{Cu}-\mathrm{Au}-\mathrm{Ag}$ Mineralization of the Tombulilato District, North Sulawesi, Indonesia. J. Geochem. Explor. 1994, 50, 221-256. [CrossRef]

7. Turner, S.J.; Flindell, P.A.; Hendri, D.; Hardjana, I.; Lauricella, P.F.; Lindsay, R.P.; Marpaung, B.; White, G.P. Sediment-Hosted Gold Mineralisation in the Ratatotok District, North Sulawesi, Indonesia. J. Geochem. Explor. 1994, 50, 317-336. [CrossRef]

8. Wisanggono, A.; Abaijah, P.; Akiro, K.; Pertiwi, D.; Sauzy, R.A. Supergene enriched, intrusion related low sulphidation deposit, binebase-bawone, North Sulawesi, Indonesia. In The Sulawesi Mineral Resources 2011 Seminar MGEI-IAGI; Masyarakat Geologi Ekonomi Indonesia (MGEI)-Ikatan Ahli Geologi Indonesia (IAGI): Manado, Indonesia, 2011; pp. 131-144.

9. Carlile, J.C.; Digdowirogo, S.; Darius, K. Geological Setting, Characteristics and Regional Exploration for Gold in the Volcanic Arcs of North Sulawesi, Indonesia. J. Geochem. Explor. 1990, 35, 105-140. [CrossRef]

10. Kavalieris, I.; Van Leeuwen, T.M.; Wilson, M. Geological Setting and Styles of Mineralization, North Arm of Sulawesi, Indonesia. J. Southeast Asian Earth Sci. 1992, 7, 113-129. [CrossRef]

11. Van Leeuwen, T.M. 25 Years of Mineral Exploration and Discovery in Indonesia. J. Geochem. Explor. 1994, 50, 13-90. [CrossRef]

12. Pirajno, F. Hydrothermal Processes and Mineral Systems, 1st ed.; Springer: Dordrecht, The Netherlands, 2009.

13. Van Leeuwen, T.M. Muhardjo Stratigraphy and Tectonic Setting of the Cretaceous and Paleogene Volcanic-Sedimentary Successions in Northwest Sulawesi, Indonesia: Implications for the Cenozoic Evolution of Western and Northern Sulawesi. J. Asian Earth Sci. 2005, 25, 481-511. [CrossRef]

14. Helmers, H.; Maaskant, P.; Hartel, T.H.D. Garnet Peridotite and Associated High-Grade Rocks from Sulawesi, Indonesia. Lithos 1990, 25, 171-188. [CrossRef]

15. Van Leeuwen, T.; Allen, C.M.; Kadarusman, A.; Elburg, M.; Michael Palin, J.; Muhardjo; Suwijanto. Petrologic, Isotopic, and Radiometric Age Constraints on the Origin and Tectonic History of the Malino Metamorphic Complex, Nw Sulawesi, Indonesia. J. Asian Earth Sci. 2007, 29, 751-777. [CrossRef]

16. Katili, J.A. Large Transcurrent Faults in Southeast Asia With Special Reference to Indonesia. Geol. Rundschau 1970, 59, 581-600. [CrossRef]

17. Sukamto, R.A.B.; Sumadirdja, H.; Suptandar, T.; Hardjoprawiro, S.; Sudana, D. Reconnaissance Geological Map of the Palu Quadrangle, Sulawesi, 1:250,000; Geological Research and Development Centre: Bandung, Indonesia, 1973.

18. Frost, B.R.; Barnes, C.G.; Collins, W.J.; Arculus, R.J.; Ellis, D.J.; Frost, C.D. A Geochemical Classification for Granitic Rocks. J. Petrol. 2001, 42, 2033-2048. [CrossRef]

19. Miyashiro, A. Volcanic Rock Series in Island Arcs and Active Continental Margins. Am. J. Sci. 1974, 274, 321-355. [CrossRef]

20. Frost, B.R.; Frost, C.D. A Geochemical Classification for Feldspathic Igneous Rocks. J. Petrol. 2008, 49, 1955-1969. [CrossRef] 
21. Pearce, J.A.; Harris, N.B.W.; Tindle, A.G. Trace Element Discrimination Diagrams for the Tectonic Interpretation of Granitic Rocks. J. Petrol. 1984, 25, 956-983. [CrossRef]

22. Hyndman, D.W. Petrology of Igneous and Metamorphic Rocks, 2nd ed.; Mcgraw-Hill Book Co.: New York, NY, USA, 1985.

23. Winter, J.D. An Introduction to Igneous and Metamorphic Petrology; Prentice Hall: Upper Saddle River, NJ, USA, 2001.

24. Bucher, K.; Grapes, R. Metamorphism of Quartzofeldspathic Rocks. In Petrogenesis of Metamorphic Rocks; Springer: Berlin/Heidelberg, Germany, 2011; pp. 395-414.

25. Van Leeuwen, T.; Allen, C.M.; Elburg, M.; Massonne, H.-J.; Palin, J.M.; Hennig, J. The Palu Metamorphic Complex, Nw Sulawesi, Indonesia: Origin and Evolution of A Young Metamorphic Terrane With Links to Gondwana and Sundaland. J. Asian Earth Sci. 2016, 115, 133-152. [CrossRef]

26. Nockolds, S.R.; Allen, R. The Geochemistry of Some Igneous Rock Series-III. Geochim. Cosmochim. Acta 1956, 9, 34-77. [CrossRef]

27. Frost, B.R.; Lindsley, D.H.; Andersen, D.J. Fe-Ti Oxide-Silicate Equilibria; Assemblages With Fayalitic Olivine. Am. Miner. 1988, 73, 727-740.

28. Robin, P.-Y.F. Theory of Metamorphic Segregation and Related Processes. Geochim. Cosmochim. Acta 1979, 43, 1587-1600. [CrossRef]

29. Robb, L.J. Introduction to Ore-Forming Processes; Blackwell Pub.: Oxford, UK, 2005.

30. Fournier, R.O. The behavior of silica in hydrothermal solutions. In Geology and Geochemistry of Epithermal Systems; Berger, B.R., Bethke, P.M., Eds.; Society of Economic Geologists: Chelsea, MI, USA, 1985; pp. $45-61$.

31. Henley, R.W.; Brown, K.L. A practical guide to the thermodynamics of geothermal fluids and hydrothermal ore deposits. In Geology and Geochemistry of Epithermal Systems; Berger, R.P., Bethke, P.M., Eds.; Society of Economic Geologists: Littleton, CO, USA, 1985; pp. 25-44.

32. Corbett, T.M.; Leach, G.J. Southwest Pacific Rim Gold-Copper Systems; Society of Economic Geologists: Chelsea, MI, USA, 1998.

33. Giggenbach, W.F. Mass Transfer in Hydrothermal Alteration Systems-A Conceptual Approach. Geochim. Cosmochim. Acta 1984, 48, 2693-2711. [CrossRef]

34. White, N.C.; Hedenquist, J.W. Epithermal Gold Deposits: Styles, Characteristics, and Exploration. SEG Newslett. 1995, 23, 1-9.

35. Simmons, S.F.; White, N.C.; John, D.A. Geological characteristics of epithermal precious and base metal deposits. In Economic Geology 100th Anniversary Volume; Hedenquist, J.W., Thompson, J.F.H., Goldfarb, R.J., Richards, J.P., Eds.; Society of Economic Geologists: Littleton, CO, USA, 2005; pp. 485-522. 